\title{
Relationship between Clinical Competency and Kolb's Learning Style for Clinical Practice Education in Nursing Students
}

\author{
Mi-Young Moon \\ Department of Nursing, Joongbu University, 201, Daehak-ro, Chubu-myeon, \\ Geumsan-gun, Chungnam, 32713, South Korea \\ mmy@joongbu.ac.kr
}

\begin{abstract}
The purpose of this study was to understand Kolb's learning style after clinical training of nursing students and to know the relevance of clinical competency according to learning type. The subjects of this study were 143 nursing students in $3 r d$ and 4th years attending one of 2 universities that completed clinical training of more than 6 weeks. Data were analyzed using SPSS 21.0 program. As a result of analyzing the difference in clinical competency according to general characteristics, it was found to be significant in school satisfaction), clinical training period, and clinical training satisfaction. In the learning style degree of the subjects, the assimilator was the most frequent with $31.5 \%$, and the accommodator with $25.2 \%$. There was a significant difference in the nursing process among the 5 sub-variables in the analysis of the difference in the clinical competency according to the learning style of the subject. There was no correlation between the learning style and clinical competency. Therefore, by focusing on the learning styles of nursing students, it is necessary to grasp the learning style according to the period rather than once and to make educational efforts for qualitative change according to the maturity and environment of the learner.
\end{abstract}

Keywords: Nursing students, Learning styles, Clinical competency, Clinical practice

\section{Introduction}

The goal of nursing education is to nurture a professional nurse who can provide quality nursing to the subjects of various health statuses through theory education and practical training. In the nursing curriculum, knowledge is learned through theory, and practical training, the knowledge and skills learned in the school are integrated to develop necessary nursing skills. For this purpose, a clinical training course that applies the theory to practice is indispensably required, and for effective clinical training education, the learning style and preferred learning method of the nursing student as the actual study subject have an important influence on nursing education [1].

For learning style, Dunn looked at the relationship between how information is learned and maintained, rather than what is learned [2], Keffe defines learning styles as relatively persistent and stable cognitive, affective, and motor-functional behaviors that show how learners perceive and interact with the learning environment [3]. As recent educational trends

Article history:

Received (March 25, 2019), Review Result (April 30, 2019), Accepted (May 31, 2019) 
have emphasized learner-centered education, the level-based curriculum has been introduced to increase interest in the diversity of learners and to provide education appropriate to individual students and this is because the viewpoint of life or how the environment interacts depends on the learning style and influences how new knowledge or skills are acquired. Therefore, to carry out effective education, it is necessary to grasp the learning style of the learner in advance and education should be done accordingly [4].

During clinical training, nursing students experience many difficulties and stresses due to a lack of clinical competency and communication skills in the process of identifying the theories learned in the classroom in the field where the nursing practice is performed and applying them to the nursing subjects [5]. The clinical training of nursing students is an important subject that should be learned before becoming a nurse, and uniform education has been done without considering the learning styles of students. Recently, as the paradigm of nursing education emphasizes performance-based education to produce students with nurse competency, the emphasis is placed on teaching-learning methods in which learners take a leading role [6]. It is expected that the learning style of nursing students can be grasped to confirm the learning achievement of clinical training and to prove that effective teaching based on learner can be achieved in the instruction of clinical training.

The purpose of this study is to identify the clinical competency according to the learning style in the clinical training education of nursing students and to provide the basic data for the clinical training education by confirming the difference according to the learning style and ultimately contribute to the qualitative development of nursing education and nursing practice improvement.

\section{Methods}

\subsection{Research design}

This study is a descriptive research study to grasp the relation with clinical competency according to the learning style of nursing students.

\subsection{Participants and data collection}

The study utilized convenience extraction to select 150 nursing students in 3 rd and 4th years attending one of 2 universities located in K province who underwent more than 6 weeks of clinical training who understood the purpose of the research and gave consent to participation, and a total of 143 copies were utilized excluding incomplete responses.

\subsection{Research tools}

\subsubsection{Kolb's learning style}

Kolb's [7] Learning Style Inventory (LSI) modified and supplemented was used. The tool consists of 12 questions in 4 descriptive sentences and the basic four scales of Concrete Experience (CE), Reflective Observation (RO), Abstract Conceptualization (AC), and Active Experiment (AE) are described on each item. It is composed of a 4 points scale from 4 best expresses their learning tendency to 1 least expresses their learning tendency. These values were used to examine whether learners were abstract, concrete, active, or reflective.

Cronbach's alpha in this study was .85 , concrete experience .425 , reflective observation .521 , abstract conceptualization .811 , and active experiment .752 . 


\subsubsection{Clinical competence}

The study is based on the clinical competency tool developed by Lee Wonhee et al. [8] based on Schwiriab [9]. This tool is composed of a total of 45 items in 5 areas of clinical competency. The five areas are nursing process (11 items), nursing skills (11 items), interpersonal relation/communication (6 items), professional development ( 9 items), and education/cooperation ( 8 items), and each item was measured on a Likert scale ranging from 1 to 'not well at all' and 5 points to 'very well', and higher scores indicate higher clinical competency.

Table 1. The general characteristics of clinical competency $(\mathrm{N}=143)$

\begin{tabular}{|c|c|c|c|c|}
\hline & & \multirow{2}{*}{$\mathrm{N}(\%)$} & \multicolumn{2}{|c|}{ Clinical competency } \\
\hline & & & mean \pm sd & $\mathrm{t}$ or $\mathrm{F}(\mathrm{p})$ \\
\hline \multirow{2}{*}{ Gender } & Male & $14(9.8)$ & $3.68 \pm 0.73$ & \multirow{2}{*}{$\begin{array}{l}-0.195 \\
(.845)\end{array}$} \\
\hline & Female & $129(90.2)$ & $3.72 \pm 0.63$ & \\
\hline \multirow{2}{*}{ Grade } & 3 rd & $124(86.7)$ & $3.74 \pm 0.67$ & \multirow{2}{*}{$\begin{array}{l}1.360 \\
(.176)\end{array}$} \\
\hline & 4th & $19(13.3)$ & $3.53 \pm 0.40$ & \\
\hline \multirow{3}{*}{ Satisfaction of College* } & Satisfiesa & $29(20.3)$ & $4.27 \pm 0.51$ & \multirow{3}{*}{$\begin{array}{c}18.666 \\
(.000) \\
\left(\mathrm{c}\langle\mathrm{a})^{* * *}\right.\end{array}$} \\
\hline & Moderateb & $95(66.4)$ & $3.61 \pm 0.56$ & \\
\hline & Dissatisfiedc & 19(13.3) & $3.35 \pm 0.71$ & \\
\hline \multirow{3}{*}{$\begin{array}{l}\text { Satisfaction of Nursing } \\
\text { major* }\end{array}$} & Satisfiesa & $40(28.0)$ & $3.98 \pm 0.57$ & \multirow{3}{*}{$\begin{array}{c}8.525 \\
(.000) \\
\left(\mathrm{c}\left\langle\mathrm{b}\langle\mathrm{a})^{* * *}\right.\right.\end{array}$} \\
\hline & Moderateb & $93(65.0)$ & $3.66 \pm 0.59$ & \\
\hline & Dissatisfiedc & $10(7.0)$ & $3.15 \pm 0.91$ & \\
\hline \multirow{5}{*}{ Major Choice Motivation } & high school record & $11(7.7)$ & $3.34 \pm 0.57$ & \multirow{5}{*}{$\begin{array}{l}1.792 \\
(.134)\end{array}$} \\
\hline & $\begin{array}{c}\text { others' } \\
\text { recommendation }\end{array}$ & $24(16.8)$ & $3.63 \pm 0.68$ & \\
\hline & $\begin{array}{l}\text { percentage of } \\
\text { employment }\end{array}$ & 49(34.3) & $3.70 \pm 0.65$ & \\
\hline & belief of nursing & $48(33.6)$ & $3.87 \pm 0.62$ & \\
\hline & etc. & $11(7.7)$ & $3.65 \pm 0.52$ & \\
\hline \multirow{3}{*}{$\begin{array}{c}\text { Academic achievement } \\
\text { (G.P.A) }\end{array}$} & Over 4.0 & $14(9.8)$ & $4.02 \pm 0.59$ & \multirow{3}{*}{$\begin{array}{l}3.023 \\
(.052)\end{array}$} \\
\hline & $3.0 \sim 3.99$ & $114(79.7)$ & $3.71 \pm 0.64$ & \\
\hline & $2.0 \sim 2.99$ & $15(10.5)$ & $3.44 \pm 0.57$ & \\
\hline \multirow{5}{*}{$\begin{array}{l}\text { Clinical practice } \\
\text { period(/week)* }\end{array}$} & under $6 a$ & $23(16.1)$ & $3.09 \pm 0.54$ & \multirow{5}{*}{$\begin{array}{c}14.395 \\
(.000) \\
\left(\mathrm{a}, \mathrm{b}\langle\mathrm{d}, \mathrm{e})^{* *}\right.\end{array}$} \\
\hline & $7 \sim 12 b$ & $14(9.8)$ & $3.26 \pm 0.56$ & \\
\hline & $13 \sim 18 \mathrm{c}$ & $12(8.4)$ & $3.72 \pm 0.56$ & \\
\hline & $19 \sim 24 d$ & $10(7.0)$ & $3.58 \pm 0.35$ & \\
\hline & over $25 \mathrm{e}$ & $84(58.7)$ & $3.97 \pm 0.56$ & \\
\hline \multirow{4}{*}{$\begin{array}{l}\text { Satisfaction of clinical } \\
\text { practice* }\end{array}$} & dissatisfieda & $8(5.6)$ & $3.56 \pm 0.81$ & \multirow{4}{*}{$\begin{array}{c}6.360 \\
(.000) \\
\left(\mathrm{b}\langle\mathrm{c}, \mathrm{d})^{* *}\right.\end{array}$} \\
\hline & moderateb & $68(47.6)$ & $3.51 \pm 0.60$ & \\
\hline & satisfyc & $60(42.0)$ & $3.90 \pm 0.57$ & \\
\hline & very satisfyd & $7(4.9)$ & $4.24 \pm 0.70$ & \\
\hline
\end{tabular}

Cronbach's alpha in this study of reliability by sub-domain was Nursing process .929 , Nursing skills .941, Nursing education/cooperation .933, Interpersonal 
relation/communication .878, and Professional development .902, Cronbach's alpha of the total items was .979.

\subsection{Data analysis}

The collected data were analyzed using SPSS 21.0 program. The general characteristics and learning styles of nursing students were analyzed using frequency and percentage, and the degree of clinical competency was analyzed by mean and standard deviation. The difference in clinical competency between general characteristics and learning styles of nursing students was analyzed by t-test, ANOVA, and Scheffe. Pearson Correlation Coefficient was used to analyze the correlation between the degree of clinical competency and the learning style of nursing students.

\section{Results}

Among the subjects of this study, $90.2 \%$ of subjects were female, satisfaction with a nursing major was analyzed as 'satisfied' $(28.0 \%)$ and satisfaction with clinical training was 'moderate' $(47.6 \%)$.

In the difference of clinical competency according to the general characteristics of subjects, school satisfaction $(\mathrm{p}<.001)$, clinical training period $(\mathrm{p}<.001)$, and clinical training satisfaction $(\mathrm{p}<.001)$ were found to be significant [Table 1].

In the learning style degree of the subjects, Diverger, Assimilator, Converger, and Accommodator were found to be $23.1 \%, 31.5 \%, 20.2 \%$, and $25.2 \%$, respectively [Table 2].

There was a significant difference in the Nursing process $(\mathrm{p}=0.33)$ among sub-variables of clinical competency in the analysis of the difference between the different clinical competencies to the learning style of the subject [Table 3].

As a result of analyzing the correlation between learning style and clinical competency, there was no significant relationship [Table 4].

Table 2. The learning style of subjects $(\mathrm{N}=143)$

\begin{tabular}{|c|c|c|c|}
\hline Learning styles & 3rd year N $(\%)$ & 4th year N (\%) & Total \\
\hline Diverger & $30(24.2)$ & $3(15.8)$ & $33(23.1)$ \\
\hline Assimilator & $26(21.0)$ & $10(52.6)$ & $45(31.5)$ \\
\hline Converger & $25(20.2)$ & $4(21.1)$ & $29(20.3)$ \\
\hline Accommodator & $43(34.7)$ & $2(10.5)$ & $36(25.2)$ \\
\hline Total & $124(100)$ & $19(100)$ & $143(100)$ \\
\hline
\end{tabular}

\section{Conclusion and suggestions}

The learning styles of Kolb vary according to the characteristics of the actual learners. Therefore, it is necessary to consider the personal environment of nursing students. Nursing education in clinical practice should identify the problems and develop problem-solving abilities in case subjects in the clinical field, and it is necessary to develop and provide a basic improvement program for this. 
Table 3. Sub-variables of clinical competency according to the learning style of subjects $(\mathrm{N}=143)$

\begin{tabular}{|c|c|c|c|c|c|}
\hline & Diverger & Assimilator & Converger & Accommodator & $\mathrm{F}(\mathrm{p})$ \\
\hline Clinical competency & $3.52 \pm 0.70$ & $3.62 \pm 0.60$ & $3.81 \pm 0.60$ & $3.86 \pm 0.62$ & $2.280(.082)$ \\
\hline Nursing process & $3.34 \pm 0.70$ & $3.51 \pm 0.64$ & $3.75 \pm 0.58$ & $3.71 \pm 0.61$ & $3.002(.033)$ \\
\hline Nursing skills & $3.49 \pm 0.71$ & $3.55 \pm 0.67$ & $3.81 \pm 0.74$ & $3.82 \pm 0.69$ & $2.162(.095)$ \\
\hline $\begin{array}{c}\text { Nursing } \\
\text { education/cooperation }\end{array}$ & $3.48 \pm 0.72$ & $3.60 \pm 0.66$ & $3.71 \pm 0.73$ & $3.82 \pm 0.69$ & $1.614(.189)$ \\
\hline $\begin{array}{c}\text { Interpersonal relations } \\
\text { / communication }\end{array}$ & $3.49 \pm 0.75$ & $3.53 \pm 0.60$ & $3.66 \pm 0.57$ & $3.85 \pm 0.62$ & $2.539(.059)$ \\
\hline $\begin{array}{c}\text { Professional } \\
\text { development }\end{array}$ & $3.47 \pm 0.72$ & $3.55 \pm 0.66$ & $3.67 \pm 0.60$ & $3.73 \pm 0.70$ & $1.131(.339)$ \\
\hline
\end{tabular}

Nursing students' learning style was found to be most convergent and adaptive. Nursing students should experience all four types of learning, so balanced and effective learning is required.

Table 4. Correlation with learning styles, clinical competency $(\mathrm{N}=143)$

\begin{tabular}{|c|c|c|}
\hline \multirow{2}{*}{} & Learning styles & Clinical competency \\
\cline { 2 - 3 } & $\mathrm{r}(\mathrm{p})$ & $\mathrm{r}(\mathrm{p})$ \\
\hline Learning styles & 1 & $.026(.758)$ \\
\hline Clinical competency & & 1 \\
\hline
\end{tabular}

\section{Acknowledgments}

Focusing on the learning style of nursing students, it is necessary to divide by the period from the entrance to graduation rather than seeing it as one, and it is necessary to grasp the learning style according to the period and to make educational efforts for the qualitative change according to the maturity and environment of the learner.

\section{References}

[1] S.L. Stradley, B.D. Buckley, T.W. Kaminski, M.Horodyski, D. Fleming, and C.M. Janelle, "A nationwide learning-style assessment of undergraduate athletic training students in CAAHEP-accredit training programs," Journal of Athle Training, vol.37, no.4, pp.S14-146, (2002)

[2] R. Dunn, "Learning style: State of the science," Theory into Practice, vol.23, no.1, pp.10-19, (1984)

[3] J.W. Keffe, “Assessing student learning style: An overview," In Student Learning Style And Brain Behavior, Reston, VA: National Association of Secondary School Principals, (1982)

[4] C. Kreber, "The relationships between self-directed learning, critical thinking, and psychological type, and some implications for teaching in higher education," Studies in Higher Educ, vol.23, no.1, pp.1-86, (1998)

[5] V. Venkatesh, M. Morris, G. Davis, and F. Davis, "User acceptance of information technology: Toward a unified view," MIS Quarterly, vol.27, no.3, pp.425-478, (2003)

[6] S.H. Kim and S.Y. Park, "Factors influencing on learning flow of nursing students," Journal of the Korea Academia-Industrial Cooperation Society, vol.15, no.3, pp.1557-1565, (2014)

[7] D.A. Kolb, "Learning style inventory," McBer \& Company, Boston, MA, (1985) 
[8] P.M. Schwrian, "Evaluating the performance of nurses: A multidimensional approach," Nursing Research, vol.27, no.6, pp.347-351

[9] W.H. Lee, J.J. Kim, H.K. Hur, K.S. Kim, and S.M. Lim, "Research for development of clinical performance measurement tool of nursing college students," Yonsei University Nursing Journal, vol.13, pp.17-29 